DOI 10.37882/2223-2982.2021.10.01

\title{
СОТРУДНИЧЕСТВО МЕЖДУ РОССИЕЙ И АЗЕРБАЙДЖАНОМ: МЕЖДУНАРОДНЫЙ ТРАНСПОРТНЫЙ КОРИДОР СЕВЕР-ЮГ
}

\section{COOPERATION BETWEEN RUSSIA \\ AND AZERBAIJAN: INTERNATIONAL NORTH-SOUTH TRANSPORT CORRIDOR \\ I. Abbasaliyev}

Summary: The article examines the significant object of cooperation between the Russian Federation and the Republic of Azerbaijan - the North-South transport corridor, its route and functions, examines the measures taken in the region in recent years to implement this project, reveals the active role of the participating countries. The author comes to the conclusion that the benefits obtained from the transport corridor will expand the geopolitical and trade opportunities of Russia and Azerbaijan.

Keywords: Azerbaijan, Russia, cooperation, North-South Transport Corridor.

\author{
Аббасалиев Илькин Сахиб оглы \\ аспирант, Дипломатическая академия \\ Министерства иностранных дел РФ \\ ilkin.abbasaliyev@yahoo.com
}

Аннотация: В статье исследуется значимый объект сотрудничества между Российской Федерацией и Азербайджанской Республикой - транспортный коридор Север-Юг, его маршрут и функции, рассматриваются меры, принятые в регионе в последние годы для реализации этого проекта, раскрыта активная роль стран-участниц. Автор приходит к выводу, что выгоды полученные от транспортного коридора, расширят геополитические и торговые возможности России и Азербайджана.

Ключевые слова: Азербайджан, Россия, сотрудничество, транспортный коридор Север-Юг.
$\mathrm{B}$ целях дальнейшего развития региона официальные Москва и Баку намерены реализовать ряд проектов с участием Ирана и Турции. В августе 2020 г. на пресс-конференции министр иностранных дел С.В. Лавров заявил, что Россия поддерживает строительство транспортного коридора Север-Юг с участием Ирана и коридора Восток-Запад с участием Турции. «Энергомост Россия-Азербайджан-Иран также является очень актуальным и востребованным проектом», - подчеркнул С.В. Лавров [11]. Проект будут реализовывать все три страны, объединив свои системы производства и транспортировки электроэнергии. Руководство Азербайджана считает очень перспективным сотрудничество в трех- или четырехстороннем формате. В рамках коридора Север-Юг Азербайджан завершил строительство новой автомагистрали между Баку и иранской границей, а в ближайшие несколько месяцев завершит прокладку еще одной дороги, соединяющей Баку с российской границей.

Россия, Иран и Индия подписали соглашение о международном транспортном коридоре (МТК) 16 мая 2002 года и являются странами-учредителями. Другими участниками проекта стали Азербайджан, Армения, Казахстан и Беларусь, кроме того, Таджикистан, Кыргызстан, Оман, Украина, Сирия имеют разный уровень участия. В настоящее время Азербайджан активно включился в строительство новых железнодорожных линий и шоссейных дорог на ряде участков коридора. Туркменистан, не являясь официальным участником, планирует установить автомобильное сообщение с коридором. В ТК есть следующие ветки [2]:

а) Центральная ветка начинается в крупнейшем в Индии порту Джавахарлала Неру в регионе Мумбаи в западном штате Махараштра на берегу Индийского океана. Затем она соединяется морским маршрутом протяженностью 1275 км с портом Бендер-Аббас в Ормузском проливе Ирана, проходит на север Ирана по суше автомобильным и железнодорожным транспортом в Ноушехр, Амирабад и к Каспийскому морю к иранскому порту Анзали, откуда направляется в порты России, Азербайджана, Туркменистана и Казахстана.

б) Западная ветка соединяет железнодорожную сеть Азербайджана с Ираном через трансграничные узловые пункты Астара (Азербайджан) и Астара (Иран), далее морским путем - с портом Джавахарлала Неру в Индии. 21 июня 2021 года западная ветка МТК была введена в эксплуатацию для отправки грузов из Вуосаари (Финляндия) в Мумбаи (Индия) - тестовая партия грузов пройдет транзитом через Россию, Азербайджан и Иран, чтобы добраться до Мумбаи за предполагаемые 22 дня по сравнению с 40 днями, которые потребовались бы для доставки через действующий Суэцкий канал и порты Западной Европы.

в) Восточная ветка соединяет Россию с Индией через страны Центральной Азии - Казахстан, Узбекистан и Туркменистан. 
MTK представляет собой многоходовую сеть судов, железных и автомобильных дорог протяженностью 7200 км для перевозки грузов между Индией, Ираном, Афганистаном, Азербайджаном, Россией, Центральной Азией и Европой. В первую очередь предполагается перевозка грузов из Индии, Ирана, Азербайджана и России морским, железнодорожным и автомобильным транспортом [15, с. 363]. Целью коридора является расширение торговых связей между такими крупными городами, как Мумбаи, Москва, Тегеран, Баку, Бендер-Аббас, Астрахань, Бендер-Энзели и т.д. В 2014 г. были проведены «сухие» рейсы по двум маршрутам: первый - из Мумбаи в Баку через Бендер-Аббас, а второй - из Мумбаи в Астрахань через Бендер-Аббас, Тегеран и Бендер-Энзели. Целью обследований было выявление и устранение основных узких мест [3]. Осмотр, проведенный Федерацией ассоциаций экспедиторов Индии, показал, что этот маршрут на 30\% дешевле и на 40\% короче нынешнего традиционного маршрута [15, с. 364].

Коридор связывает Мумбаи с Москвой через два южных иранских порта, Бендер-Аббас и Чабахар, проходя через Баку, который расположен вдоль западного берега Каспийского моря. Основная цель нового пути сократить затраты времени и денег по сравнению с используемым в настоящее время традиционным маршрутом. Аналитики прогнозируют, что благодаря улучшению транспортного сообщения между Россией, Центральной Азией, Ираном и Индией объемы их двусторонней торговли существенно увеличатся [12]. Маршрут коридора через Азербайджан обеспечивает транспортное сообщение между Индией, Ираном, Азербайджаном, Россией и Казахстаном. Иран начал строительные работы по завершению недостающего звена автодороги и железной дороги Казвин-Решт-Астара (205 км), включая участок Решт-Астара (164 км). Он предполагает строительство 369 км мостов и железнодорожной ветки, которые свяжут южные участки с северными. После их завершения на маршруте будут построены еще 22 новых туннеля и 15 мостов [5].

В марте 2013 г. Иран открыл порт Астара, расположенный на юго-западном каспийском побережье. Порт был интегрирован в коридор, чтобы улучшить сообщение через море. Иран инвестировал в порт 22 млн долларов и планирует увеличить инвестиции на 10\% для расширения порта. Его мощность составляет 600000 т, но есть планы увеличить ее до 3 миллионов т. Содружество Независимых Государств (СНГ) - основные производители зерна, которое будет экспортироваться в Африку через иранский порт Бендер-Аббас. Он позволит быстрее и дешевле доставлять российские товары во внутренние провинции Ирана. Через этот же порт продукция из России, Азербайджана, Казахстана, Туркменистана наиболее быстрым способом может быть отправлена в Индию [4].
В 2015 г. президент Ильхам Алиев санкционировал ускорение работ на азербайджанском участке коридора, что привело к строительству железнодорожной линии между одноименными городами Астара в Азербайджане и Астара в Иране, которая вступила в эксплуатацию в 2017 г. [14]. Азербайджан является значимым партнером в реализации проекта благодаря своему географическому положению между Ираном и Россией, развитой инфраструктуре и инвестиционным возможностям. Азербайджан также продвигает сооружение железной дороги Астара (Иран) - Решт (Азербайджан), которая является основным недостающим звеном в коридоре. Азербайджан тесно сотрудничает с Российской Федерацией для более эффективной эксплуатации коридора. Прогнозы на основе имеющихся исследований свидетельствуют о том, что МТК обеспечит доступ в европейские страны, Россию, Среднюю Азию и Кавказ, к Персидскому заливу и Индии, а также укрепит торговые отношения с черноморскими портами прикаспийских государств. В частности, грузы, поступающие на железнодорожную линию Казвин-Решт-Астара (Иран) - Астара (Азербайджан), доставляются напрямую из Азербайджана в Россию, а оттуда в страны Европы.

С января по октябрь 2019 г. товарооборот Ирана с Азербайджаном составил 422,68 млн долларов, что на 30,7\% больше, чем в соответствующий период 2018 г. Экспорт Ирана за 10 месяцев составил 391,69 млн долларов, что на 30,1\% превышает показатели аналогичного периода прошлого года [8]. Первый поезд через коридор, отправившийся из Хельсинки 21 июня 2021 г., достиг пункта назначения в два раза быстрее, чем по традиционному маршруту через Суэцкий канал, что доказывает своевременность и конкурентоспособность этой транспортной артерии [7]. Однако, помимо коммерческих выгод, коридор имеет еще и геополитическое значение. Он связывает Россию с регионом Персидского залива, Индийским океаном и Европой, будет способствовать укреплению Евразийского экономического союза, облегчая торговлю между странами-членами и одновременно развивая прилегающие российские регионы, кроме того, МТК может стать для России средством противодействия Китаю.

Коридор очень важен также для развития отношений между Азербайджаном и Россией, повышения их престижа, усиления позиций на Южном Кавказе и в Каспийском регионе. За последние годы в обеих странах в этом направлении было много сделано по созданию транспортно-логистического центра и совершенствования транспортной инфраструктуры. МТК, соединяющий через Азербайджан страны Северо-Западной Европы, Каспийского бассейна и Персидского залива, Центральной и Юго-Восточной Азии, является многофункциональным, а включение в его структуру дорог и морских путей дает ему дополнительные преимущества [16]. Про- 
ект имеет особое значение и для расширения отношений Азербайджана с его крупнейшим экономическим партнером - Евросоюзом.

В этом контексте цели Соглашения о МТК заключаются в следующем:

а) Повышение эффективности транспортных связей для организации перевозки пассажиров и грузов в Азербайджане и России по международному транспортному коридору Север-Юг;

б) содействие выходу Азербайджана и России на международный рынок услуг железнодорожного, автомобильного, морского, речного и воздушного транспорта;

в) содействие в увеличении объема международных пассажирских и грузовых перевозок в Азербайджане и России;

г) обеспечение безопасности движения, надлежащего хранения товаров и защиты окружающей среды в соответствии с международными стандартами.

Соглашение регулирует международные и транзитные перевозки пассажиров и грузов через территорию стран различными видами транспорта по маршрутам, определяемым компетентными органами. Оно остается в силе в течение десяти лет с момента его вступления в силу. Обязательства по нему и другим соглашениям, подписанным в соответствии с положениями настоящего Соглашения, действуют до его полного выполнения и даже после его прекращения [10]. Азербайджан и Россия предоставляют другим странам-партнерам право международного транзита пассажиров, товаров и транспортных средств через территорию своих стран на условиях, предусмотренных Соглашением. При этом обе страны оказывают им помощь в международной транспортировке товаров через территорию своих стран. 92-километровая дорога, начинающаяся с 45-го километра автомобильной дороги Баку-Губа-граница России строится в соответствии с технической категорией 1Б [6, c. 2].

Азербайджан также берет на себя транспортировку природного газа из России по южному газопроводу из Баку через Турцию в Европу. Президент Государственной нефтяной компании Азербайджана (SOCAR) Ровнаг Абдуллаев и генеральный директор итальянской компании «Снам» Карло Малакарне подписали Меморандум о сотрудничестве для оценки инициатив, выдвинутых для развития Бакинских газовых месторождений. Стороны обсудили возможность обмена опытом в области строительства и эксплуатации оборудования, необходимого для транспортировки газа через итальянскую инфраструктуру [18].

Одна из основных целей проекта - возродить древ- ние транспортные пути и соединить Индийский океан с Персидским заливом и Каспийским морем. Это более короткий путь между Россией, Индией и Бангладеш через Иран и государства Центральной Азии, и Азербайджан может сыграть большую роль в транспортировке грузов по этому маршруту, поскольку он проходит по его территории [9]. Кроме того, Азербайджан и Россия сотрудничают в поставках иранских товаров. Тегеран ищет способы использовать новые транспортные возможности в своих интересах. Этой цели служила региональная поездка министра иностранных дел Ирана Джавада Зарифа в Армению, Азербайджан, Грузию, Россию и Турцию в январе 2021 г. В частности, главным пунктом повестки дня этой серии зарубежных визитов было предложение о возобновлении функционирования советской железной дороги, соединяющей Иран и Армению через азербайджанский эксклав Нахчыван [17]. Некоторые скептики высказывают сомнения по поводу экономической эффективности устаревших железнодорожных путей советских времен для Ирана и России, обновление которых потребует огромных вложений. Более того, США и Европейский союз могут распространить свои санкции против Ирана и России на эти инфраструктурные проекты, если они будут рассматриваться как укрепление регионального гегемонистского потенциала Тегерана и Москвы. Реализация проекта МТК будет иметь значение и для дальнейшего экономического сотрудничества Азербайджана и Индии. В 2018 г. товарооборот между ними составил 930 млн долларов. Кроме того, в Азербайджане действуют около 230 компаний с индийским капиталом, вложившие в экономику 1,2 млрд долларов [14].

В ходе развития железнодорожной сети в Каспийском регионе и Центральной Азии на сегодня имеется несколько вариантов маршрута коридора. Ожидается, что недостающий железнодорожный участок АстараРешт будет достроен в ближайшее время. По западному направлению уже осуществлены тестовые отправки грузов из Индии в Россию и обратно, даны характеристики вариантов маршрута по дальности перевозки, сроков доставки и стоимости транспортировки товаров. В настоящий момент стоимость перевозок даже по западной ветви МТК значительно превышает стоимость транспортировки через Суэцкий канал. Ввиду этого и других факторов, снижающих эффективность и конкурентоспособность перевозок по коридору, предлагается в первую очередь организовать контейнерные перевозки на участке МТК между Россией, Азербайджаном и Ираном. Такие способы транспортировки могут стать особенно востребованными для продовольственных товаров (в том числе скоропортящихся) по направлению с юга на север. В итоге проект МТК сблизит Россию и Азербайджан в геополитических вопросах, будет побуждать страны-участницы развивать взаимовыгодное сотрудничество и заключать соглашения с другими союзами. 


\section{ЛИТЕРАТУРА}

1. араваев А., Тишехьяр М. Международный транспортный коридор «Север — Юг» и сценарии трансрегиональной интеграции. Доклад Международного дискуссионного клуба «Валдай». М.: Фонд развития и поддержки Международного дискуссионного клуба «Валдай», 2019. 35 с.

2. Международный транспортный коридор «Север-Юг» улучшит сообщение между Индией и Россией с помощью более дешевых мультимодальных транзитных маршрутов (Интернет-ресурс) https://www.russia-briefing.com/news/mezhdunarodnyj-transportnyj-koridor-sever-yug-uluchshit-soobshheniemezhdu-indiej-i-rossiej-s-pomoshhyu-bolee-deshevyh-multimodalnyh-tranzitnyh-marshrutov.html/ (17.09.2021)

3. Министерство иностранных дел Российской Федерации, Международный транспортный коридор «Север - Юг» (Интернет-pecypc) https://www.mid.ru/ foreign_policy/economic_diplomacy/ism_communication/-/asset_publisher/fajfwCb4PqDA/content/id/2510952 (02.09. 2021)

4. РИА Новости. Международный транспортный коридор (МТК) «Север - Юг» (Интернет-ресурс) https://ria.ru/20171101/1507611427.html (02.09.2021)

5. ТАСС. Лавров: создание коридора «Север - Юг» особенно важно после инцидента в Суэцком канале (Интернет-ресурc) https://tass.ru/ekonomika/11128467 (02.09.2021)

6. Azərbaycan «Şimal-Cənub beynəlxalq nəqliyyat dəhlizi» infrantrukturunu təkmilləşdirir, Azərbaycan. 2018.12 oktyabr. S. 2.

7. Chalikyan N., Tashjian Y. Geopolitics of the North-South Transport Corridor (Интернет-ресурс) https://southasianvoices.org/geopolitics-of-the-north-southtransport-corridor/ (04.09.2021)

8. Financial Tribune. 30\% Rise in Iran's Trade with Azerbaijan (Интернет-ресурс) https://financialtribune.com/articles/domestic-economy/100863/30-rise-in-iranstrade-with-azerbaijan (06.09.2021)

9. Hasan P. The International North-South Transport Corridor: What Is the Potential For Bangladesh? 8 August 2021 (Интернет-ресурс) https://www.silkroadbriefing. com/news/2021/08/08/the-international-north-south-transport-corridor-what-is-the-potential-for-bangladesh/ (08.09.2021)

10. «Şimal-Cənub» Beynəlxalq Nəqliyyat Dəhlizi haqqında Sazişə qoşulmaq barəsində Azərbaycan Respublikasının Qanunu (№ 984-IIQ), Bakı şəhəri. 20 sentyabr 2005-ci il (Интернет-ресурс) http://www.e-qanun.az/framework/10740 (01.09.2021)

11. Xinhua. Russia, Azerbaijan to implement regional projects with Iran, Turkey (Интернет-ресурс) http://www.xinhuanet.com/english/2020-08/26/c_139320192. $\mathrm{htm}(01.09 .2021)$

12. INSTC (Интернет-ресурс) http://www.instc-org.ir/Pages/Home_Page.aspx (01.09.2021)

13. Islamic Development Bank. A Study of International Transport Corridors in OIC Member Countries. Report. September 2011. $226 \mathrm{p}$.

14. Mammadli N., North-South Transportation Corridor Could Be A Boon for Azerbaijan \& India (Интернет-ресурс) https://caspiannews.com/news-detail/northsouth-transportation-corridor-could-be-a-boon-for-azerbaijan-india-2019-11-29-33/ (05.09.2021)

15. Meltem Müftüler-Baç, Deniz Başkan. The Future of Energy Security for Europe: Turkey's Role as an Energy Corridor, Middle Eastern Studies. 2011. 47:2. 361-378.

16. Məmmədov S., «Şimal-Cənub» beynəlxalq nəqliyyat dəhlizi regional inkişafa təkan verəcək. Xalq qəzeti (Internet resursu) https://xalqqazeti.com/az/news/1274 (02.09.2021)

17. Rahimov R. Iran Seeks to Reroute North-South Transport Corridor to Armenia, Away from Azerbaijan (Интернет-ресурс) https://jamestown.org/program/iranseeks-to-reroute-north-south-transport-corridor-to-armenia-away-from-azerbaijan/ (05.09.2021)

18. Zanaltay Z. Current Situation of the International North South Transport Corridor, Eurasian Research Institute, Akhmed Yassawi University (Интернет-ресурс) https://eurasian-research.org/wp-content/uploads/2020/06/aae-bulten-en-34.pdf (05.09.2021)

(с) Аббасалиев Илькин Сахиб оглы (). ilkin.abbasaliyev@yahoo.com 